\section{Allergy $_{\mathrm{and}}$ Immunology}

\title{
Felix Milgrom
}

\author{
October 12, 1919 to September 2, 2007
}

Felix Milgrom, Distinguished Professor Emeritus of Microbiology at the University at Buffalo School of Medicine and Biomedical Sciences, died unexpectedly on September 2, 2007 following a short illness.

Dr. Milgrom was born in Poland on October 19, 1919 and obtained his MD degree from the University of Wroclaw, Poland, in 1946 on the basis of a dissertation devoted to serological mass examinations for syphilis. In 1951 he obtained the title of Privatdozent for his work on the structure of natural antibodies. He was a faculty member of the School of Medicine at Wroclaw from 1946 to 1954 , where he closely collaborated with Ludwik Hirszfeld, the famous Polish microbiologist and mentor and father figure to Dr. Milgrom. In the academic year 1953-1954, Dr. Milgrom was Professor of Microbiology at the University of Wroclaw and Acting Director of the Institute of Immunology and Experimental Medicine of the Polish Academy of Science (now the Ludwik Hirszfeld Institute of Immunology). Thereafter, he became Professor and Chairman of the Department of Microbiology in the Silesian University School of Medicine, Zabrze, Poland, in 1954-1957, and, after leaving Poland, he was associated with Pierre Grabar at the Pasteur Institute, Paris, in 1957.

In 1958, at the invitation of Dr. Ernest Witebsky, he joined the Department of Bacteriology and Immunology at the University of Buffalo (now the Department of Microbiology and Immunology of the UB School of Medicine and Biomedical Sciences, State University of New York). Beginning as Research Associate, he rose to the rank of Professor and was appointed chairman of the Department in1967, succeeding Witebsky. He was one of the founding members of the Center for Immunology, now

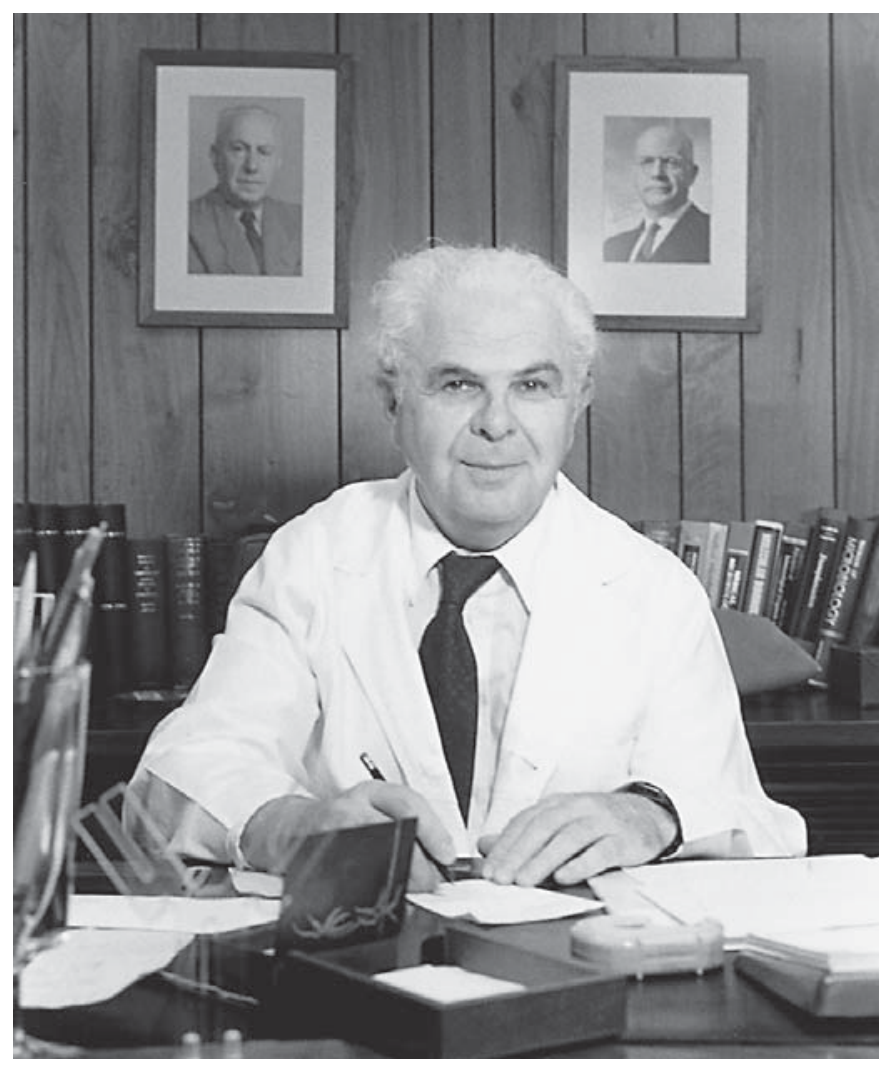

known as the Witebsky Center for Microbial Pathogenesis and Immunology, and was Acting Director of this center in 1969-1970 and 1973-1974. Dr. Milgrom was named a SUNY Distinguished Professor in 1981 for his long and fruitful career in teaching, research, and administration. After 18 years of distinguished leadership,

\section{KARGER}

Fax +41613061234 E-Mail karger@karger.ch www.karger.com
(C) 2008 S. Karger AG, Base

$1018-2438 / 08 / 1462-0174 \$ 24.50 / 0$ 
which included expansion of the number and diversity of specialty of the faculty, a greatly increased graduate program, and development of a broad base of basic science research in immunology and microbiology, Dr. Milgrom stepped down as chairman of the Department in 1985, citing Benjamin Franklin who said that it is a promotion when a public servant becomes a private citizen. After leaving administration, Dr. Milgrom devoted the rest of his professional life to teaching and research. He was author or coauthor of over 400 publications and mentored nearly 100 graduate students and postdoctoral fellows.

Felix Milgrom was one of the few scientists of his time who had a deep knowledge of the entire field of immunology. Much of his early research involved studies on natural antibodies. These studies showed that the combining site of an antibody may have more than one specificity. Also, before IgM antibodies were described, he was the first to show that an antibody molecule may have more than two combining sites.

Additional work on antibody molecules showed that new antigenic sites on the IgG molecule are revealed by interaction with antigen. This led to work demonstrating that sera from rheumatoid arthritis patients may contain antibodies directed against IgG. He obtained experimental evidence for this by showing that rabbits, immunized for a long period of time either with a foreign antigen or with their own denatured IgG, formed antibodies to IgG.

Dr. Milgrom also did extensive work in the area of organ transplantation. He was the first to demonstrate that certain renal homograft rejections are caused by anti- bodies in the recipient's circulation that react with the grafted tissue. In his work on heterophile antibodies, he was the first to propose and provide evidence that PaulBunnell antibodies are produced in response to a novel antigen arising in the course of infectious mononucleosis

In addition to the above work Dr. Milgrom made significant contributions in other areas of immunology, including blood groups, autoimmunity, tumor immunology and renal immunopathology.

Dr. Milgrom's accomplishments were recognized by the awarding of five honorary doctor of medicine degrees: by the University of Vienna, Austria, in 1976; by the University of Lund, Sweden and the University of Heidelberg, Germany, in 1979; by the University of Bergen, Norway, in 1980, and by the University of Medicine and Dentistry of New Jersey, Newark, in 1991. Among many other honors, he received the Paul Ehrlich and Ludwig Darmstaedter Prize in 1987.

Dr. Milgrom, always true to his academic heritage, was fond of citing a poem which was given to him by his spiritual grandfather, Emil von Dungern:

You wanted to look into the face of nature

And for this you fought all your life.

Still you did not pierce Nature's shield

And everlasting nature defeated you

And unfulfilled remain your longings.

I know this well but still we keep fighting.

C. John Abeyounis, Buffalo, N.Y., USA 